\title{
TYPOLOGIES OF AGREEMENT: SOME PROBLEMS FROM KAYARDILD
}

\author{
By NichOLAS Evans \\ University of Melbourne
}

'that rarity, nouns.., those most reluctant agreers, agreeing in case, of all categories' (Plank 1995:32)

\begin{abstract}
In this paper I describe a number of agreement-type phenomena in the Australian language Kayardild, and assess them against existing definitions stating both the boundaries of what is to be considered agreement, and characteristics of prototypical agreement phenomena. Though conforming, prima facie, to definitions of agreement that stress semantically-based covariance in inflections on different words, the Kayardild phenomena considered here pose a number of challenges to accepted views of agreement: the rich possibilities for stacking case-like agreement inflections emanating from different syntactic levels, the fact that inflections resulting from agreement may change the word class of their host, and the semantic categories involved, in particular tense/aspect/mood, which has been claimed not to be an agreement category on nominals. Two types of inflection, in particular - 'modal case' and 'associating case' - lie somewhere between prototypical agreement and prototypical government. Like agreement, and unlike government, they are triggered by inflectional rather than lexical features of the head, and appear on more than one constituent; like government, but unlike agreement, the semantic categories on head and dependent are not isomorphic. Other types of inflection, though unusual in the categories involved, the possibility of recursion, and their effects on the host's word-class, are close to prototypical in terms in how they fare in Corbett's proposed tests for canonical agreement.
\end{abstract}

Note to typesetters:

(a) I don't have access to the hachek symbol, which needs to be used several places over the $\mathrm{c}$ in the name Mel'cuk instead of the c. At each relevant place I have written [insert hachek] after the letter c.

(b) Tables are currently at end of document and need to be inserted. 


\section{INTRODUCTION ${ }^{1}$}

Kayardild is remarkable in the degree to which featural information, no matter what syntactic level it is introduced at, percolates down to all constituent words, sometimes resulting in three or four layers of morphosyntactic feature specifications (especially case and other case-like phenomena), iconically layered so that outer affixes have a more remote syntactic source. This creates, in spades, the sort of informational redundancy we associate with more canonical types of agreement. ${ }^{2}$ The multiply layered featural representations that result create special challenges for delineating agreement, that we examine in this paper: in general, it pushes out the typological space of what can be considered as agreement, whether canonical or not.

In §2 I give a brief sketch of Kayardild grammar, introducing en route the various phenomena which have a prima facie case to be considered agreement. In \$3 I see how far these various phenomena fit with a range of definitions of agreement in the literature, considering also whether some of them are better analysed as government. Whereas $\$ 3$ concentrates on whether they lie within the outer boundaries of the phenomenon, in $\S 4 \mathrm{I}$ attempt to locate them with respect to canonical agreement, as characterised by Corbett (in press). §5 summarises the general problems that Kayardild poses to typologies of agreement.

\section{INTRODUCTION TO KAYARDILD}

Kayardild is one of the Tangkic languages spoken in Queensland, Australia, in the Wellesley Islands and adjoining mainland. The family comprises three main languages: Lardil, Kayardild, and Yukulta. Additional and now extinct varieties are Yangkaal and Nguburindi; the limited materials we have on these show Yangkaal to be a sister dialect of Kayardild, and Nguburindi a sister dialect of Yukulta. Within Tangkic, the family bisects into 'northern Tangkic', comprising Lardil alone, and

\footnotetext{
${ }^{1}$ I thank Matthew Baer, Dunstan Brown, Bernard Comrie, Grev Corbett, Marianne Mithun, Edith Moravcsik, Rachel Nordlinger, Carole Tiberius and an anonymous referee for comments on earlier versions of this material, and my Kayardild teachers Darwin Moodoonuthi, Roland Moodoonuthi, Roma Kelly, Pat Gabori, Netta Loogatha and others (see preface to Evans 1995a for full acknowledgments) for helping me to understand their language over many years. My discussions with the Surrey Morphology Group and attendance at the 2002 Agreement Workshop were supported by ESRC (UK) grant R000238228, whose assistance is gratefully acknowledged.

${ }^{2}$ On the other hand, it gives individual words a great deal of potential pragmatic autonomy: a noun, for example, may carry information not just about its own case role (say, genitive), but also about the case role of the noun it is modifying, and also about the tense/aspect/mood of the clause it occurs in, and, for good measure, about the relation of its own clause to higher clauses or levels of discourse information. See Evans (1993) on the potential of multiplyinflected individual words to scaffold specified interpretations under ellipsis.
} 
'southern Tangkic', comprising Yukulta and Kayardild. The Tangkic languages have no close relatives, though they are related, at a distant level, to other Australian languages and share most grammatical similarities with languages along the Roper River well to the west. All are severely endangered: Kayardild, which is the healthiest, has fewer than ten fluent speakers. The major sources on these languages are: for Yukulta, Keen (1983), for Lardil, Hale (1973, 1997) and Klokeid (1976), and for Kayardild, Evans (1995a,b).

The Tangkic languages are typical of Australian languages in employing a rich system of case suffixes, which allow for great freedom of word order. Beyond this, their case systems are perhaps the most remarkable in the world for several interrelated reasons, which we outline in the next five subsections (\$2.1-2.5). We also discuss, in $\$ 2.6$, agreement within the 'verbal group' in TAMP categories.

\subsection{Double case marking}

Firstly, they exhibit 'double case marking', 3 since one NP embedded in another inflects both for its own case (e.g. the possessive) and that of its head: cf (1) and (2). ${ }^{4}$ This is basically a corollary of the fact that case is marked on all elements of NPs, and that 'adnominal case', used to relate one NP to another in genitive, proprietive and other relations, is not suppressed before following 'relational' case indicating thematic and/or grammatical relations at clause level. The marking of case over NPs, whether it functions adnominally or relationally, is the first candidate phenomenon for 'agreement' in Kayardild.

\section{(1) ${ }^{5}$ thabuju-karra wangalk}

\footnotetext{
${ }^{3}$ In this they are by no means unique, either in Australia or in the world. See Dench \& Evans (1988) for a survey of the phenomenon in Australian languages, and Plank (1995) for a more substantial typological overview.

${ }^{4}$ It is natural to ask whether adnominal case marking can be recursive, in the equivalents of phrases like '(with) the man's wife's clothes'. This is a question which the perilous state of the language has left it impossible to answer: I have no absolutely clearcut examples in naturally-occurring sentences, but remain unclear whether this reflects an accidental gap, the impact of processing constraints on frequency, or a categorical prohibition against recursive uses of adnominal case. The closest naturally-occurring examples I have are dulk-uru-karra dangka-karra malaa [country-PROP-GEN man-GEN sea] 'the country-owner's sea', lit. 'the country-having person's sea', and a structurally equivalent and effectively synonymous version with the ablative instead of the genitive, i.e. dulk-uru-na dangka-na malaa [country-PROP-ABL man-ABL sea], both of which were uttered by elder Pat Gabori during a Native Title claim. Now the proprietive, genitive and ablative can all function adnominally, and can be construed as adnominals here, which would make this an example of double adnominal case (albeit not followed by a further case, or at least one other than the nominative, which is zero). However, against this analysis one could argue that dulkuru dangkaa is a fixed phrase, and that the -uru here is functioning derivationally rather than as a productive adnominal use.

${ }^{5}$ The practical orthographies used for these languages employ digraphs for a variety of phonemes, making use of $r$ before a stop or nasal letter to denote retroflexion - thus $r d$ for $/ \mathrm{d} /$ and $r n$ for $/ \mathrm{\eta}$ ! - and $h$ after a stop or nasal letter
} 


\section{brother-GEN ${ }^{6} \quad$ boomerang.NOM}

'brother's boomerang' ${ }^{7}$

(2) dan-kinaba-nguni dangka-naba-nguni mirra-nguniwangal-nguni

this- ABL-INSTR man-ABL-INSTR good-INSTR boomerang-INSTR

' ... with this man's good boomerang.'

\subsection{Modal case}

A peculiar typological development in Kayardild and Lardil is that what are etymologically case suffixes have taken on an additional function, of marking mood/tense/aspect. These inflections, which I refer to as 'modal case' inflections, are still formally identical with regular case inflections, ${ }^{8}$ and appear on most non-subject NPs, after any other regular or adnominal case inflections that have been assigned. (In addition, tense/aspect/mood/polarity (TAMP) is marked in a more typologically usual way on the verb). (3a) gives a Kayardild example using the 'modal ablative' (glossed M.ABL) together with past tense verb inflection, while (3b) shows how the 'modal proprietive' (glossed M.PROP), together with the 'potential' verb inflection, conveys futurity or ability. In each example, modal case appears on the object and instrument NPs; with objects it is the only case (i.e. there is no accusative case, the object relation being inferrable from the presence of the modal case marker, which does not appear on the subject), but with instruments it follows the instrumental. ${ }^{9}$

to denote a lamino-interdental articulation (with the blade of the tongue between the teeth) - thus $t h \mathrm{for} / \mathrm{t} / \mathrm{and} n h$ for $/ \mathrm{n} /$. Other graphemes, standard in Australian orthographies, are $n g$ for $/ \mathrm{r} J /, n y$ for $/ \mathrm{j} /, r r$ for $/ \mathbb{Y} /, r$ for $/ \mathrm{d} /$ and $j$ for $/ t_{\mathrm{g}} /$. Distinctive vowel length is shown by doubling the letter, e.g. a a for $/ a$ :/.

${ }^{6}$ The following abbreviations are used in glosses: ABL(ative), ACT(ual), APPR(rehensive), DAT(ive), GEN (itive), INSTR(rumental), LOC(ative), NEG(ative), NMSR(nominaliser), NOM(inative), OBL(ique), POT (ential), PROP(rietive), P(a)ST, S(in)G(ular), TAMP 'tense / aspect / mood / polarity'. Before case glosses, M. indicates 'modal function' (\$2.2), C indicates 'complementizing' function (\$2.3), A indicates 'associating function’ (\$2.4) and $\mathrm{V}$ indicates 'verbalizing case', e.g. V.D. 'verbalizing dative'; no special functional abbreviation is used before adnominal or relational uses of case.

${ }^{7}$ Actually thabuju means 'elderbrother', but since this is not a paper about kinship I only give approximate English glosses for such terms.

${ }^{8}$ The formal identity is substantial: it includes base forms, patterns of allomorphy, combinatorial restrictions on suffix sequences, and a distinctive portmanteau form for one combination. The only departure from formal identity is the existence of 'final' and 'non-final' forms; these are largely parallel but there are some minor differences. See Evans (1995a) for full details.

${ }^{9}$ Other oblique relations for which modal case marking follows a role-marking case include the allative and utilitive. See Evans (1995a:412) for details. 


$\begin{array}{llll}\text { dangka-a } & \text { burldi-jarra } & \text { yarbuth-ina } & \text { thabuju-karra-nguni-na } \\ \text { man- NOM } & \text { hit-PST } & \text { bird-M.ABL } & \text { brother-GEN-INSTR-M.ABL }\end{array}$

wangal- nguni-na

boomerang-INSTR-M.ABL

'the man hit the bird with brother's boomerang.'

(3b)

$\begin{array}{llll}\text { dangka-a } & \text { burldi-ju } & \text { yarbuth-u } & \text { thabuju-karra-ngun-u } \\ \text { man- NOM } & \text { hit-POT } & \text { bird-M.PROP } & \text { brother-GEN-INSTR-M.PROP }\end{array}$

wangal- ngun-u

boomerang- INSTR-M.PROP

'the man will / can hit the bird with brother's boomerang.'

The full set of cases involved in the modal case system is given in Table 1.

\section{Insert Table 1 about here.}

It may help the reader grasp this highly unusual phenomenon if its diachronic origins are summarized. Briefly, the extension from ablative to past originated by first marking it on subordinate 'prior' clauses, on both verb and its dependents, and then using such subordinate clauses as main clauses; the extension from proprietive to potential/future involved a fusion of two constructions: a semi-transitive main-clause construction in which 'intentional objects' of verbs like 'wait for X' and 'look for X' were marked with the proprietive ('wait, having X (in mind)'), and a subordinate construction of purpose in which the proprietive case was marked on verb and its dependents. ${ }^{10}$

\footnotetext{
${ }^{10}$ Much of the how this strange evolution occurred has now been reconstructed (see McConvell 1981, Evans 1995a, Chapter 10) with the help of data from Yukulta, the most conservative Tangkic language and representative of the proto-Tangkic situation. Like many Australian languages, Yukulta is ergative, marking transitive subjects with one case (the ergative), but intransitive subjects and objects with another (the absolutive). However, there are various conditions in which Yukulta replaces the ergative construction with alternatives in which the subject takes the absolutive and the object takes the locative, dative or proprietive ('having') case, depending on such factors as the person of subject and object ('I hit him' uses the ergative construction, but 'he hit me' uses the nominative-dative),
} 
Returning to our main theme, the covariation of tense/aspect/mood marking on verbs and NPs is a second prima facie candidate for being considered 'agreement' in Kayardild. Indeed, Hale's earliest description of the equivalent phenomenon in Lardil described object case-marking as manifesting 'agreement with the tense of the verb' (Hale 1973:421). Later writings on Lardil by Hale's student Klokeid substituted the term 'concord':

'Concord [which he has just been discussing in connection with case agreement within the NP - N.E.] is relevant in other circumstances as well. If a tense category is present in a clause, then that tense appears not only on the verb, but also distributes to its dependents, excepting only the subject... These categories further distribute to the dependents of the verb dependents.' Klokeid (1976:520)

Likewise, Hale (1998:199), again using the term 'concord' rather than agreement, describes Lardil as exhibiting 'overt suffixal tense ... concord, spreading on to the heads in the verb phrase it locally governs'.

Note further that even the forms of the verbal and modal case inflections in (3) are similar - both end in $u$, and (in specialized contexts not exemplified here) both expand to -uru before the 'complementizing locative' and to - $и и$ before the 'complementizing oblique' (see below). This has a historical explanation: both originate as proprietive case markers with clausal scope, marked on inflected verbs and nominals alike in subordinate clauses of purpose: the potential clause

the degree of reality involved (e.g. real vs wished-for event), and negation. So many conditions call for the alternative constructions, in fact, that the basic ergative construction is only rarely employed in Yukulta. It appears that in Kayardild and Lardil these alternative constructions became so predominant that the original ergative construction was lost; the cognates of the ergative, dative and proprietive have all become tense-sensitive object markers (modal case) in Kayardild and/or Lardil.

A second factor in this development, and the main reason why modal case ends up being marked over most NPs in Kayardild and Lardil, was the generalization into main clauses of what in Yukulta is purely a subordinate clause type. For example, to say 'he chopped wood, to light a fire', Yukulta says 'he chopped wood, light-PROPRIETIVE fire-PROPRIETIVE', i.e. 'having lighting, having fire (in mind)', putting the proprietive case to mark the 'having a purpose' relation on every word of the subordinate clause. Through a process of 'insubordination', by which the subordinate clause structure is co-opted for main clause use, Kayardild and Lardil have developed structures like "he light-PROPRIETIVE fire-PROPRIETIVE' as their way of saying 'he will / wants to light a fire'.

The first factor - oblique constructions - can be considered a case of government, while the second (case distribution over a subordinate clause) is agreement over a clausal constituent. The blending of these two constructional sources in the Kayardild and Lardil modal case systems may account for why modal case displays mixed properties of agreement and government. 
construction derives, by a diachronic process of insubordination (Evans 1995a, forthcoming), from a purpose clause in which the proprietive marked the purpose relation. Diachronically, then, this once was agreement.

Synchronically, however, the relation between the two sites is one of partial parallelism rather than agreement (see Table 1 again for a summary of the correspondence between modal case and verbal TAMP categories). Holding the modal case constant at the Modal Proprietive, for example, one can vary the verb's polarity into the Negative Potential, as in (4a), or the Apprehensive, as in (4b). Or, holding the verbal inflection constant at the Potential, one can vary the modal case into the Modal Locative (4c), giving the meaning 'was able to', i.e. using the Modal Locative to locate, in 'Actual' (realized) modality, the ability denoted by the verbal Potential inflection.

(4a) dangka-a

burldi-nangku yarbuth-u

thabuju-karra-ngun-u

man- NOM

hit- NEG.POT

bird-M.PROP

brother-GEN-INSTR-M.PROP

wangal- ngun-u

boomerang- INSTR-M.PROP

'The man will not / cannot hit the bird with brother's boomerang.'

(4b) ngada burldi-nyarra ngumban-ju thabuju-karra-ngun-u

$1 \mathrm{sg}$ NOM hit- APPR 2sg-M.PROP brother-GEN-INSTR-M.PROP

wangal- ngun-u

boomerang- INSTR-M.PROP

'(watch out or) I might hit you with brother's boomerang'

(4c)

barruntha-y dangka-a burldi-ju yarbuth-i

yesterday-M.LOC man-NOM hit-POT bird-M.LOC

'the man was able to hit the bird yesterday'

Note in passing the the modal locative also appears on the time nominal 'yesterday' - in general, modal case appears directly on time and place nominals. On the other hand, a number of NP types do not take modal case - most notably the subject, but also various types of secondary predicate on the subject, nouns denoting body parts of the subject, and NPs displaying other semantic links with 
the subject, such as proprietive NPs denoting 'private goals'. See Evans (1995a:\$10.3) for fuller discussion of the precise domain of modal case than can be given here.

\subsection{Complementizing case}

A third typologically unusual feature of Kayardild case inflections is a further 'complementizing' use of case suffixes, to indicate various types of interclausal relations such as being a clausal complement, as illustrated by the 'complementizing' use of the oblique in (5a). Note that it goes on all words of the subordinate clause, outside any other inflections. Clauses taking complementizing case normally take the oblique case, except that if their subjects are first person inclusive they take the locative (if their subjects are second person they may take either). Locative complementizing case is blocked from appearing on pronouns, which therefore default to the nominative, but otherwise appears everywhere in the clause (5b).

(5a) ngada kurri-ja,

1SG.NOM see-ACT

dangka-ntha burldi-jarra-ntha yarbuth-inaa-ntha

man-COBL hit-PST-C.OBL bird-M.ABL-C.OBL

thabuju-karra-nguni-naa-ntha wangal- nguni-naa-nth

brother-GEN-INSTR-M.ABL-C.OBL boomerang- INSTR-M.ABL-C.OBL

'I saw that the man had hit the bird with brother's boomerang'

(5b) bilda kurri-ja,

3PL.NOM see-ACT

ngakulda bakiin-ki burldi-jarra-ya yarbuth-inaba-ya

12- NOM all-C.LOC hit-PST- C.LOC bird-M.ABL-C.LOC

thabuju-karra-nguni-naba-ya wangal- nguni-naba-y

brother-GEN-INSTR-M.ABL-C.LOC boomerang- INSTR-M.ABL-C.LOC

'they saw that we all (including you) had hit the bird with brother's boomerang' 
Complementizing case originated as agreement of an entire subordinate clause with a case-marked antecedent, but changes in case-marking in the main clause have obscured this - see Evans 1995a:543-549 for discussion.

As with 'modal case', complementizing case forms are identical in form, combinatorics, and idiosyncratic sequence restrictions to 'normal' case suffixes. Addition of complementizing case can result in sequences of up to four case morphemes, as with thabuju-karra-nguni-naa-ntha in and thabuju-karra-nguni-naba-ya in (5b), built up from an adnominal genitive, an instrumental by agreement with its head noun, a modal ablative, and a complementizing oblique or locative.

\subsection{Associating case}

When a verb is placed in its 'nominalised' form - essentially a participle-like construction that may mark it as heading certain types of dependent clause, or as indicating continuous aspect if used in a main clause - all NPs in its clause, except the subject and a few NP types linked with it (e.g. secondary predicates on the subject), take an 'associating oblique' case after any other case suffix they may have, adnominal, relational, and/or modal. If the nominalised clause is independent, as in (6), there is no modal case, but if it modifies an antecedent in a higher clause (7) both the nominalised verb and all NPs in the nominalised clause bear the same modal case as the antecedent. In such cases, the associating oblique is placed, anti-iconically, ${ }^{11}$ outside the modal case, even though it originates at a more local site (the nominalised verb in its own clause, rather than the NP antecedent in the higher clause).

(6) ngadayalawu-n-da yakuri-nja thabuju-karra-nguni-njamijil-nguni-nj

1SG.NOM catch- NMSR-NOM fish-A.OBL brother-GEN-INSTR-A.OBL net-INSTR-A.OBL

'I am catching fish with brother's net'

(7) ngada kurri-jarra bilwan-jina [ yalawu-n-kina

1SG.NOM see-PST them-M.ABL catch-NMSR-M.ABL

yakuri-naa-ntha thabuju-karra-nguni-naa-ntha mijil-nguni-naa-nth ]

\footnotetext{
${ }^{11}$ See Evans (1995b) for an account of how this anti-iconic ordering may have arisen.
} 
fish-M.ABL-A.OBL brother-GEN-INSTR-M.ABL-A.OBL net-INSTR-M.ABL-A.OBL

'I saw them catching fish with brother's net'

\subsection{Verbalizing case $^{12}$}

A further strange feature of case in the Tangkic languages is that there is an additional set of case inflections, semantically and structurally part of the set of 'normal' case inflections but with the peculiarity that they convert their hosts, morphologically, from nouns into verbs. (See Evans 1995a for arguments that, although they have been morphologically converted to verbs, the hosts retain the syntactic characteristics of nominals).

Beneficiaries in Kayardild, for example, take the 'verbalizing dative' case -maru-, which then takes regular verbal inflections (8a), but which is distributed across all words in the noun phrase like a case inflection. (Etymologically this derives from a verb meaning 'put' but structurally it is now a part of the Kayardild system of case suffixes.) Nouns bearing such verbalizing case inflections take exactly the same set of TAMP inflections as the verb - unlike NPs bearing modal case, they inflect for polarity, for example ( $8 b)$ - and, moreover, just like a main verb they can be nominalised (8c), and don't take associating case.

(8a)

ngadawaa-jarra wangarr-ina ngijin-maru-tharra thabuju-maru-tharra.

1SG.NOM sing-PST song-M.ABL my-V.DAT-PST brother-V.DAT-PST

'I sang a song for my brother'

(8b)
ngadawaa-nangku
wangarr-u
ngijin-maru-nangku thabuju-maru-nangku.
1SG.NOM sing- NEG.POT
song-M.PROP $m y$-V.DAT-NEG.POT
brother- V.DAT-NEG.POT

'I won't sing a song for my brother'

\footnotetext{
${ }^{12}$ In earlier publications (e.g. Evans 1995a) I have used the term 'verbal case', but since this is rather ambiguous (it could also mean 'case marked on verbs') I have switched to calling it 'verbalizing case' in this paper, to emphasise the way it changes the word-class of its host. I likewise use terms like 'verbalizing dative' instead of the 'verbal dative' used in earlier publications.
} 

ngadawaa-n-da
wangarr-inja ngijin-maru-n-da

1SG.NOM sing- NMSR-NOM song-A.OBL

$m y$ - V.DAT-NMSR-NOM

thabuju-maru-n-d.

brother- V.DAT-NMSR-NOM

'I am singing a song for my brother'

Agreement in TAMP between the main verb and nominals inflected for verbalizing-case constitute a counter-example to the claim by Lehmann \& Moravcsik (2000:742) that '[w]hile there may be agreement between a nominal dependent and its verb in other categories, tense is not an agreement category. Even where both the noun and the verb have tense, tense is selected independently for a verb and its nominal dependents'.

\subsection{The verbal group}

In addition to the case-like phenomena outlined in $\$ 2.1-\$ 2.5$, there is one further site for agreementlike phenomena: what I will call the 'verbal group', a sequence of serialized verbs consisting of an obligatory main verb plus up to two further verbs, functioning as markers of associated motion, adverbial quantification, and aspect. Unlike normal conjoined verbs, which are either freely ordered (if in the one clause), or separated by a pause (if in separate clauses), verbs in a verbal group have a fixed order, with the lexical verb first, and belong to a single intonational grouping. In many cases the meaning of the complex is non-compositional - for example, adding the verb thaa-tha 'return' after a motion verb $\mathrm{V}$ gives the total meaning ' $\mathrm{go}$ off and $\mathrm{V}$ ' rather than ' $\mathrm{V}$ and return' ${ }^{13}$, so that (9a) can be used, for example, of a situation where the subject has not (yet) returned, in contrast to (9b), which simply conjoins two verbs with an intonation break - this can only be used if thaa-tha 'return' is directly predicable of the subject. All verbs in a verbal group take identical inflections for TAMP (9a), and if the head verb is nominalized, all nominalize (9c). In (9b) we are not dealing with a verbal gruop: it is 'accidental' that the two verbs agree in taking the Actual inflection, for example

\footnotetext{
${ }^{13}$ It is worth clarifying how this differs from the English and Japanese ways of characterising the three-part of event of going off, Ving, and returning: English 'go and V' overtly expresses the first two (implicating the third), Japanese ' $\mathrm{V}$ and return' overtly expresses the last two, and in this may appear to parallel the Kayardild construction. The point about Kayardild, in contrast to Japanese, is that this construction can be used even where no returning has actually taken place (see (10) below).
} 
one could replace thaa-tha with the potential form thaa-thu, to give the meaning 'he swam (somewhere), but will return'.

(9a) niya kuujuu-ja thaa-th.

3SG.NOM swim- ACT return- ACT

'he's gone off for a swim'

(9b) niya kuujuu-j, thaa-th.

3SG.NOM swim- ACT return- ACT

'he swam, and came back'

(9c) nyingka kurri-n-da warra-n-da wirdi-n-da

2SG.NOM see-NMSR-NOMgo- NMSR-NOM $\quad b e$ - NMSR-NOM

'You're going round to see (people) a lot.'

\section{HOW MUCH AGREEMENT?}

On the most inclusive definitions of agreement, each of the phenomena discussed in $\$ 2.1-\$ 2.6$ above is a type of agreement. Consider the definition of agreement given in P. Mathews' Oxford Concise Dictionary of Linguistics (1997:149): a '[s]yntactic relation between words and phrases which are compatible, in a given construction, by virtue of inflections carried by at least one of them', or the definition of 'concord or 'agreement" given on p. 95 of David Crystal's (1997) Cambridge Encyclopaedia of Language. Second Edition (Second edition):

Grammatical links between words are often signalled by concord or 'agreement'. A form of one word requires a corresponding form of another... 
Turning to definitions aimed at more technical audiences, we find many others which, though formulated more precisely, are similar in spirit: ${ }^{14}$

The term agreement commonly refers to some systematic covariance between a semantic or formal property of one element and a formal property of another. (Steele 1978:610)

Agreement is simply the systematic variation in form that arises from the fact that information coming from two different sources about a single object ${ }^{15}$ must be compatible.... [T] hough agreement information may appear to flow in diverse directions in particular examples, the grammar of agreement is nothing more than a system of constraints identifying certain bundles of agreement information with other such bundles, and hence requiring all such information to be compatible. (Pollard \& Sag 1988:237-238)

Agreement in the Russian grammatical tradition denotes those means of registering subordinative links between (two) members of a syntactic construction, through which the forms of the dependent and head elements are characterized by one and the same value for the category of gender, number, case (for nominals), or number, gender or person (for verbs). It is considered, that the dependent element always comes to resemble the head, and that the head element in an agreement construction is always a nominal. (Apresjan 1982:176) ${ }^{16}$ [note - the

\footnotetext{
${ }^{14}$ Note also Mel'c[inset hachek]uk's (1994:233) definition of the corresponding French term, accord: 'Catégories d'accord, dont les éléments 'reflètent' les valeurs des catégories correspondantes ou celles des traits de syntactique apparaissant dans les actants du verbe et de cette façon établissent le lien entre le verbe et ses actants' [categories of concord, whose elements 'reflect' the values of corresponding categories or syntactic features appearing in the actants of the verb, and in this way establish a link between the verb and its actants - translation mine]. This brings in a specific directionality, predicated on the assumption of a particular direction of agreement, which does not apply to many of the cases discussed here, but otherwise remains in the same spirit with its emphasis on informational equivalence.
}

${ }^{15}$ Pollard \& Sag do not explain 'object' here. On my reading, they mean something like 'informational entity' rather than 'object in the real world'; if, however, they mean the latter, then their definition of agreement would obviously be difficult to apply to situations where tense, aspect or mood are involved.

${ }^{16}$ My translation; the original is: 'Soglasovaniem v russkoj grammaticheskoj traditsii nazyvaetsja takoj sposob oformlenija podchinitel'noj svjazi mezhdu chlenami (binarnoj) sintaksicheskoj konstruksij, pri kotorom formy zavisimogo i glavnogo chlenov xarakterizujutsja odnimi i temi zhe znachenijami kategorij roda, chisla, padezha (dlja imen) ili chisla, roda ili litsa (dlja glagolov). Schitajetsja, chto zavisimyj chlen vsegda upodobljaetsja glavnomu i chto glavnym chlenom soglasovannoj konstruktsij vsegda javljaetsja sushchestvitel'noe' [Apresjan 1982: 176] 
first part is compatible with there being no 'controller'; second part assumes that the nominal is the controller]

[A] grammatical constituent A will be said to agree with a grammatical constituent B in properties $\mathrm{C}$ in language $\mathrm{L}$ if $\mathrm{C}$ is a set of meaning-related properties of $\mathrm{A}$ and there is a covariance relationship between $\mathrm{C}$ and some phonological properties of a constituent $\mathrm{B} 1$ [e.g. an affix - N.E.] across some subset of the sentences of language L where constituent B1 is adjacent to constituent $B$ and the only meaning-related non-categorial properties of constituent B1 are the properties C (Moravcsik 1978:333) ${ }^{17}$

Depending on exactly how one applies these definitions, most or all of the following Kayardild phenomena would count as agreement; 'modal case' and 'associating case' fit least well:

(a) case agreement realized on the dependents of a relational or adnominal NP, exemplified by the instrumental on 'good' in (2), or the ablative on the adnominal possessive 'this', also in (2). The existence of Suffixaufnahme means that dependents in adnominal phrases, such as 'this' in (2) are exhibiting 'multiple agreement' (see Moravcsik 1995: 460), by agreeing both with a proximal head, and with the head of the NP that governs it. ${ }^{18}$

Incidentally, note that case agreement includes that between words in a phrase inflected for verbalizing case, e.g. (8) above, with the odd consequence that the morpheme encoding agreement is effecting a change in (morphological) word class from noun/adjective to verb.

(b) modal case (\$2.2) which could be analysed as agreement of NPs with the TAMP categories on the verb. Certainly it satisfies virtually all the definitions of agreement given above: it constrains verb

\footnotetext{
${ }^{17}$ In the main body of her 1978 article, Moravcsik concentrates on agreement in gender, number and person, her initial discussion of the article's scope makes it clear that case and other categories should, in principle, be included: 'The focus of discussions will actually be ... limited .. partly in that of the various kinds of phenomena that were listed above as falling within the scope of our working definition of agreement, only those instances will be discussed where the ageed-with constituent is a nominal or a noun phrase; and of these, only those where the agreement features are features of gender, or of number, or of person, and not those of definiteness or case.' (p. 336). In a more recent publication (Moravcsik 1995:458) she describes double case-marking 'as an instance of agreement ... most closely related to instances of agreement-by-percolation, such as adjective-noun agreement in case and number'.
} 
and selected NPs to be 'compatible ... by virtue of inflections' (Matthews), it requires that a form of one word covary with 'a corresponding form of another' (Crystal), it exhibits 'systematic covariance' (Steele), resulting from the requirement that 'all such information be compatible' (Pollard \& Sag).

As indicated in $\$ 2.2$, Hale and Klokeid regarded tense-sensitive case-marking in Lardil as agreement. For Kayardild the situation is more complicated because of the greater independence of verbal TAMP and modal case but there are enough examples of agreement where the match is not exact that we should not simply rule this out.

An alternative suggested by Grev Corbett (p.c.) would be to treat it as 'government' of the NPs' case by the verbal inflection, grounded on the relative lack of isomorphism between verbal inflection and modal case categories. Certainly, as a relationship between a verb and a NP, it fits within both senses of Matthews' (1997:149) definition of 'government', as '1. [t] he relation between a *head (1) and an *object or other complement.', and '2. A relation between such a head and the *case of an object.'

While treating modal case as government would 'save' the clarity of 'agreement', however, it would do so at the cost of stretching the notion of 'government'. Firstly, we would need to allow government to be 'parallel' in the sense of governing the same choice of modal case on a number of different NPs (e.g. object, time phrase, location, utilitive). Secondly, we would need to relax our definition of government so that it is not seen as stemming just from lexical properties of the governor (as implied, for example, by the useful definition in Apresjan 1982:181) ${ }^{19}$, but can also stem from inflectional values. The nub of the problem lies in deciding just how much informational overlap and categorial isomorphism one requires between two elements before one calls them 'agreement'. Compare Lyons' (1968:241) characterisation of the contrast (he uses the term 'concord' as a synonym for agreement - see p. 239 of the same reference):

\footnotetext{
${ }^{18}$ Though see Lehmann (1982:205) for good arguments that the agreement is not with the head word, but with the NP node itself, such as the fact that case choice in Russian must integrate number information stemming from the numeral in the phrase.

19 'Traditsionnoe ponjatije upravlenija stroitsja na antiteze "upravlenie" vs. "soglasovanie". Upravleniem nazyvaetsja takoj sposob oformlenija podchinitel'noj svjazi mezhdu chlenami (binarnoj) sintaksicheskoj konstruktsii, pri kotorom kosvennyj padezh ili predlozhno-padezhnaja forma zavisimogo sushchestvitel'nogo odnoznachno predopredeljaetsja ne formoj glavnogo chlena, a samym glavnym chlenom v tselom, ego slovarnymi svojstvami.' [The traditional conception of government is built on the antithesis 'government' vs 'agreement'. Government denotes those means of registering subordinative links between (two) members of a syntactic construction, through which an oblique or prepositional case form of a dependent nominal is unambiguously determined, not by the form of the head element, but by the head taken as a whole, by its lexical properties] (Apresjan 1982:181; translation mine)
} 
$[U]$ nder concord two or more words or phrases are 'inflected' for the same category (e.g. number or person), whereas under government the principal and the dependent member of a syntactic construction do not both exhibit the same category: instead the dependent member is determined with respect to the relevant category (e.g. case) by the principal member. [italics original]

It may be that Kayardild modal case represents a sort of hybrid relationship somewhere between agreement and government.

(c) complementizing case (\$2.3) which exhibits agreement in case of all words in the clause, though it is less clear what the controller is. Here, then we have systematic covariance conditioned by the construction as a whole rather than any controlling head.

Note also that because the choice of complementizing case is affected by the person of the subject, we could also talk of agreement in person between the (words bearing) complementizing case, though here we are pushing the boundary between agreement and conditioning.

(d) associating case ( $\$ 2.4)$, where a 'compatible form' of inflected nouns, i.e. one bearing an outer 'associating oblique', must be chosen if the verb is nominalized. Again, the covariation of verbal nominalization and associating case corresponds to the Crystal, Matthews, Steele and Pollard \& Sag definitions of agreement. And again, as with modal case, it fits the definition of 'government' as well, being a relation between a verbal head and its object(s) and other dependents, so that with associating case we appear to have another hybrid phenomenon somewhere between canonical agreement and canonical government.

Intuitively, however, associating case fits the definition of agreement less well than modal case does. Firstly, the information on verb and host NP is less obviously of the same type - the verb is specified as being nominalized, while the noun is specified as taking an associating oblique (much in the same way that nominalized verbs in many languages govern the genitive, with the exception that the associating oblique is added on to other cases rather than simply replacing them - see Dench \& Evans 1988): this is reminisicent of one of the criteria Mel'c[inset hachek]uk uses (1996:271) to distinguish government (=régime) from agreement (= accord), namely that the governed inflectional category should not be 'conjoint' with the governing category. Secondly, whereas the inflection on the verb effects a change in morphological word class (from verb to nominal), that on the NP leaves its constituents unchanged in word class. 
(e) the TAMP inflection on nouns bearing verbalizing case (\$2.5) which agree in TAMP (and also in nominalization, which is coded at the same locus as TAMP) with the main verb. This, again, fits well with all definitions of agreement given above. Words like thabujumarutharr in (8a) may thus bear a verbalizing case that is governed by the verb's case frame (e.g. the verbalizing dative in some case frames of 'give'); the verbalizing case then, agrees in TAMP with the verb - in other words a given word may at the same time be governed by (in its verbalizing case) and agree with (in its TAMP) the main verb.

The exact matching of TAMP features, and the phonological identity of the final inflections with those on the main verb, make this look like a canonical case of agreement (except for the semantic content and the locus (on nouns). The only departures from canonical agreement concerns the lack of directionality, and the fact that the category is clausal rather than lexical. In other words, one cannot make a convincing case that the TAMP inflections, on nominals inflected for verbalizing case, are controlled by those on the verb, since an equally plausible account is that both verb and nominals simply reflect, in parallel, the clausal semantics of tense, aspect and mood. This means that the agreement relation is symmetrical rather than asymmetrical.

(f) the TAMP inflection on verbs within a verbal group (\$2.6), all of which agree in TAMP inflection with the head verb (again, this may include nominalization as well). On the surface, this looks like a very similar case to (e), except that now it is agreement between straightforward verbs rather than between a verb and nominals whose inflections have converted them into morphological verbs. However, there is a crucial difference between these and TAMP agreement on NPs bearing verbalizing case: in some constructions, one cannot derive the choice of TAMP inflection on certain non-head verbs directly from the clausal semantics: the only plausible source is direct agreement with the head verb. Consider (10), derived from (9a) above by placing it in the past tense.
niya kuujuu-jarra thaa-tharr.
3SG.NOM swim- PST return- PST
'he went off for a swim'

This can be uttered in a situation where the subject went off to swim: the swimming is clearly located in the past, but the 'returning' need not be (a narrator could go on, for example, to say that the subject had, unexpectedly, yet to return). The past is used because of a rule that all words in a verbal group must agree in TAMP, not because it is independently locating 'returning' in the past. 


\section{BUT IS IT CANONICAL?}

I argued in the previous section that most of the above six phenomena should be considered agreement; the situation with modal case is unclear, veering towards government, while the situation with associating case is much more akin to government. If my arguments are accepted, the typology of agreement needs to be expanded in a number of ways, which I outline in $\$ 5$. The above arguments, however, were oriented to the question of whether these phenomena lie inside the category boundary for agreement. As we know from prototype semantics, however (see, for example, Taylor (1995)), categories with a typical prototype-based rather than classical definition throw up two sorts of question: what is the boundary, and how close do given instances lie to the categorial focus? I now turn to this second type of question, evaluating each of the six phenomena against the measures of canonical agreement set out in Corbett (in press). Table 2 summarizes how all six perform against the nineteen criteria set out there; for reasons of space I can only discuss some of the more interesting cells here.

\section{[Insert Table 2 about here]}

To begin with, there are many cells where it is hard to apply Corbett's criteria. For example, what is the controller for complementizing case? At best, it is either the construction itself, or a condition on successive topics; in neither case is it clear what 'controller present' would mean here, what the controller's part of speech could be, or what value the features of complementizing case should then match. (This of course raises the issue of whether 'agreement' requires a controller at all, if the complementizing case is to be included as agreement). I have placed question marks in such cells. The inapplicability of six out of nineteen tests to complementizing case is the main reason it scores so low (the score of 10 is in fact out of 13 applicable tests).

Second, note that with regards to single controllers, the target is taken to be the word, not the morpheme. Since nouns can inflect multiply, for controllers at different degrees of remove, this means that they can agree with multiple controllers. With verbs this is less obvious, but multiple controllers are possible here, because (a) the verb may be nominalized, then potentially agreeing in modal case with its antecedent (b) even verbs taking 'finite' TAMP inflections may take an outer complementizing case. Words bearing verbalizing case can also have multiple controllers, since (a) they may bear an adnominal case inside the verbalizing case (e.g. in 'for the woman's brother', 'woman' would take first a genitive, then an agreeing verbalizing case: maku-karran-maruth) (b) like verbs, they can be nominalized and/or take complementizing case, which give them a couple 
more ways of accumulating inflections. These considerations mean that, for every phenomenon considered in this paper, the target word may agree with more than one controller. (See Comrie's paper in this issue for a summary of problems arising when there are competing controllers for one morphological slot; in the Kayardild case, though, we are talking about multiple morphological slots, though still on the one word, for different controllers. If we restrict our definition to "per morphological site', then the phenomena look more canonical, since there is then never more than one controller).

Third, note that only two of the phenomena are clearly asymmetric: for associating case, it is clear that formal changes to the verb are the controller, and for TAMP inflection over the VC, the semantic considerations discussed in (3f) indicate clearly that the choice of verbal inflection emanates from the head verb of the complex. For complementizing case, the lack of an identifiable controller makes the symmetry question irrelevant, while for the other three the question of symmetry depends on your analysis, for various reasons. For 'standard' case agreement (across NPs, and onto adnominal NPs from head NPs), if one adopts a dependency grammar analysis where case values flow from head to dependent, case agreement is asymmetric, whereas if one adopts a constituency-based model where all words in a constituent must match in assigned case, a symmetric account can be given. For Modal case and the TAMP inflections on nominals bearing verbalizing case, if a constructive-case approach is adopted, which builds structure from the inflections on individual words, each treated as a site for encoding the relevant TAMP information (Nordlinger 1998), the construction is symmetric: choices of verb inflection and modal case inflection are independently made on the basis of the semantics of the clause and of the relevant inflectional set. On the other hand, it is not outrageous to argue for an analysis where tense/aspect/mood information percolates down from the verb to NPs in the clause, in which case it is asymmetric (though this analysis then needs to account for the cases where modal case is varied independently of the TAMP inflection on the verb). Overall, with regard to asymmetry, only associating case and TAMP inflection on verbs in a verbal group display indubitable asymmetries, though with associating case the asymmetry may in fact be a symptom of government rather than agreement, as was discussed above.

Fourth, in no case is the controlling feature lexical. Presumably this reflects the unlikelihood of case or tense/aspect/mood ever being associated with particular lexical items, rather than being operators at clause or NP level.

Fifth, all candidates except associating case do well on the alliterative test. Even with modal case, which otherwise scores second lowest on Corbett's criteria, some values are alliterative as a result of the etymological origins of some verbal inflections as verb thematics plus case markers (which were also marked on NPs in the same clause): modal proprietive $\{-k u r u\} /$ verbal potential $\{-$ THuru $\}$; 
modal allative $\{$-kiring- $\}$ / verbal inceptive $\{$-THiring- $\}$; modal oblique $\{$-inja $\} /$ verbal hortative $\{$ THinja \} (see Evans 1995a for the details, not discussed here).

Turning from particular criteria to a discussion of overall scores, case agreement and TAMP inflections on verbs in a VC give the highest scores (16 17 and 18 respectively). Each fails the single-controller and lexical-feature tests, and case agreement passes or fails the asymmetry test according to the analysis. TAMP inflection on nominals bearing verb case also scores high, at 15 16, dropping a point because of the presence of conditions (interpreting the presence of a verbalizing case suffix as the condition). Intuitively, all these three - case agreement, TAMP inflection on nominals bearing verbalizing case, and TAMP inflection within the verbal complex - are all good exemplars of semantic agreement - and semantic agreement will normally be symmetrical and non-lexical, accounting for two each of their lost points.

Associating case also scores well, at 15 , failing the alliterative and matching-feature tests but picking up on asymmetry. This high score is somewhat odd, given the arguments advanced in $\S 3$ that it is more like government than agreement, though as admitted there it does exhibit a mix of characteristics of both types.

For modal case, the other type for which standard definitions of agreement only fit partially, the score is an unsurprisingly low 12.5. In addition to the tests failed by the others, it fails the 'matching values' test (because of the only partial match between its semantic features and those on the main verb) and the 'no choice' test (because of the possibility of varying it independently of verbal TAMP); it is also only partly alliterative.

For complementizing case, the significance of the low score of 10 is compromised by the fact that so many of the criteria cannot readily be applied, so that it is effectively 10/13 rather than 10/19. For those criteria which can be clearly applied, it behaves very similar to the best candidates for agreement discussed above.

Because of the problem of knowing where one draws the boundary, once multiple independent criteria are used, it may be useful to return to the other characterisation given in Corbett's paper, in terms of three principles that describe canonical agreement:

Principle I: Canonical agreement is redundant rather than informative

Principle II: Canonical agreement is syntactically simple

Principle III: The closer the expression of agreement is to canonical (i.e. affixal) inflectional morphology, the more canonical it is as agreement.

The application of these principles to the six Kayardild phenomena under consideration is given in Table 3. (Note that syntactically simple, as Corbett describes it, comprises two elements: controllers 
should be consistent rather than hybrid, and the controller's part of speech is irrelevant. It also brings in criteria $3,4,(6), 10,11,12,13,14,15,17,18$ and 19)

[Insert Table 3 about here]

On these criteria, three of the six phenomena count as canonical agreement, fully conforming to all three principles: case agreement, and TAMP inflection on nominals bearing verbalizing case and on verbs in a VC: they are redundant, syntactically simple (which does not mean syntactically familiar - nor that all have yet been successfully modelled by formalized syntactic models ${ }^{20}$ ), and clearly inflectional. Modal case also comes close - it meets the 'syntactically simple' and 'inflectional' criteria, and is highly, though not $100 \%$ redundant - there is a small percentage of cases $(<5 \%)$ where the modal case cannot be predicted from the verbal TAMP inflection. Associating case is not wholly redundant, since it signals the syntactic relation of the NPs it is marked on to a nominalized verb, even though it is completely predictable, but otherwise conforms to all principles. Complementizing case is clearly inflectional, and 'syntactically simple' (though, again, yet to be formally modelled), but is not wholly redundant: it needs to be marked on one word

per clause (e.g. the verb) to signal the overall syntactic and discourse function of the clause, ${ }^{21}$ but marking it on every word of the clause leads to extreme redundancy.

On these more global criteria, then, three of the six phenomena qualify as canonical agreement, and a fourth (modal case) comes close. The three phenomena that conform to these more global principles - case agreement within NPs, and TAMP inflection on nominals bearing verbalizing case, and on verbs in a VC - are, unsurprisingly, also the three that score best on Corbett's 19 tests, building a strong argument for considering all three to be clear cases of agreement. And none do worse than two out of three, suggesting that either all phenomena discussed in this paper should be considered (at least non-canonical) agreement, or else that the criteria under discussion need to be supplemented, at least, by tests that discriminate agreement from government.

\section{ConClusion}

\footnotetext{
20 To date, formalized syntactic models capable of handling some features of multiple case agreement have been proposed by Andrews (1996) and Nordlinger (1998). No-one has yet developed a formal model capable of handling verbalizing case.

${ }^{21}$ In fact, since there is also a contrast between object-topic constructions, where the object NP does not take complementizing case, and regular complementized constructions, where it does, marking of the complementizing case on (at least one) member of the object NP is also non-redundant.
} 
Taking into account the material discussed in the previous two sections, Kayardild exhibits several types of agreement that have not previously been reported:

(a) agreement of NPs with the verb in tense/aspect/mood polarity. In the case of TAMP agreement on nominals bearing verbalizing case, this involves exact matching of the relevant features with those of the verb, though the agreement is 'symmetrical', in the sense that both verb and NPs bearing verbalizing case directly reflect the semantics of tense, aspect, mood and polarity.

With 'modal case', on the other hand, the match is less exact, and the phenomenon sits somewhere between agreement and 'parallel government', a term I introduce to cover the situation where several NPs receive the same case specification governed by a verbal category. Nonetheless, the phenomenon does not match 'government' very well either, since it is determined by inflectional rather than lexical characteristics of the verb (cf. the remarks of Apresjan, above).

(b) agreement of all words in a clause with each other in 'complementizing case', which indicates the clause's status with respect to higher constituents. In this case it is difficult to specify a controller for the agreement.

(c) agreement of all elements of a verbal complex in TAMP with the head verb. Here the controller is clearly the head verb, since TAMP inflections on some words in the verbal complex cannot be independently motivated semantically.

(d) marking of most non-subject NPs with an 'associating oblique' case when the verb is nominalized, which can result in several of them sharing this case. Since both the most plausible feature value (case = associating oblique) and the form ( (i)nja, -nhtha) of the words in the NP does not directly match that on the verb (final inflection $=$ nominalisation; form $=-n-$ ) this looks less like agreement and more like (parallel) government.

(e) the far-reaching patterns of percolation found in Kayardild mean that words may simultaneously exhibit agreement with a number of other constituents, each at a different level, dramatically illustrating the need to allow agreement features to be nested.

(f) the phenomena of verbalizing case and (inflectional) nominalization both illustrate the need to allow agreement to be realized by inflectional morphemes that change the word class of the word they attach to, insofar as verbalizing case and 
inflectional nominalizations are distributed, respectively, across all words in a NP and all words in a verbal group. ${ }^{22}$

Obviously, none of the above phenomena are instances of canonical agreement. (a), (b), (c) and (f) do not exist, to my knowledge, outside the Tangkic languages, making them clear outliers in terms of how the world's languages organize their agreement systems. Nonetheless, they do largely conform to standard definitions of agreement, showing that the boundaries, if not the focus, of the category 'agreement' need to be overtly reconceptualized to allow agreement of nouns with verbs in tense/aspect/mood/polarity, nesting of agreement features emanating from different levels, and the process of registering agreement to change the word class of the host. A central task of typology is to extend the analytic concepts originally developed for familiar Indo-European languages in a way that retains their essence, but which sheds assumptions that a broader sampling of the world's linguistic diversity shows to be over-restrictive.

In many ways, Kayardild is a language with a great deal of agreement, in the familiar sense of grammatically-stipulated featural compatibility between different words. But it just happens to manifest agreement by unfamiliar semantic categories, on unfamiliar targets, over unfamiliar domains, in unfamiliar directions, with unfamiliar patterns of nested multiple agreement, with unfamiliar consequences for the morphological word-class membership of the target, and with unfamiliar functions. If we are to accommodate this by an updated typological terminology - and the unpalatable alternative is to turn away and consign the phenomena to sui generis descriptions that then fail to engage with cross-linguistic generalizations - we need to give up on a number of standard assumptions regarding the boundaries of the phenomenon.

Nicholas Evans

Department of Linguistics \& Applied Linguistics

University of Melbourne

Parkville, Victoria 3010

Australia

\footnotetext{
${ }^{22}$ Note that, for the purposes of this paper, it is not problematic that the case assigned to an NP results in a wordclass change, since case assignment can be presumed to be a matter of government. However it IS problematic that, inside a NP, all words agree with their head in taking an inflection (e.g. the verbalizing dative) that changes word class. A similar problem arises, in nominalized clauses, from agreement between a main verb, other verbs in the verbal groups, and any NP taking a verbalizing case, in taking the nominalizing inflection.
} 
Evans: Typologies of agreement - some problems from Kayardild

email:n.evans@linguistics.unimelb.edu.au 


\section{REFERENCES}

ANDREws, AVERY, 1996. Semantic case-stacking and inside-out unification. Australian Journal of Linguistics 16, 1-55.

APRESJAN, JuRI, 1982. 'O vozmozhnosti opredelenija lingvisticheskix ponjatij', Russian Linguistics 6, 175-196.

Corbett, Greville G., in press. 'Agreement: canonical instances and the extent of the phenomenon', in Janet DeCesaris, Geert Booij, Angela Ralli \& Sergio Scalise (eds.) Studies in Theoretical Morphology: Selected papers from the Third Mediterranean Morphology Meeting, Barcelona 2001. Available at: http://www.surrey.ac.uk/LIS/SMG/projects/agreement/

Crystal, David, 1997. The Cambridge Encyclopaedia of Language. Second Edition. Cambridge: Cambridge University Press.

Dench, Alan \& Nicholas D. Evans, 1988. 'Multiple case-marking in Australian languages', Australian Journal of Linguistics 8, 1-47.

Evans, Nicholas D., 1992. Kayardild dictionary and ethnothesaurus, Melbourne: University of Melbourne Department of Linguistics.

Evans, Nicholas D., 1993. 'Code, inference, placedness and ellipsis', in William A. Foley (ed.) The role of theory in linguistic description, Berlin: Mouton de Gruyter, 243-280.

Evans, Nicholas D., 1995a. A grammar of Kayardild, with historical-comparative notes on Tangkic, Berlin: Mouton de Gruyter.

Evans, Nicholas D., 1995b. 'Multiple case in Kayardild: anti-iconic suffix ordering and the diachronic filter', in Frans Plank, ed., Double case: agreement by Suffixaufnahme. Oxford: Oxford University Press, 396-428.

Hale, Kenneth L., 1973. 'Deep-surface canonical disparities in relation to analysis and change: an Australian example', in Thomas A. Sebeok (ed.), Current Trends in Linguistics 8: Linguistics in Oceania, The Hague: Mouton, 401-458.

Hale, Ken, 1997, 'Remarks on Lardil Phonology and Morphology', in Ngakulmungan Kangka Leman, Lardil Dictionary, Gununa, Queensland: Mornington Shire Council, 12-56.

Hale, Ken, 1998, 'On endangered languages and the importance of linguistic diversity', in Lenore A. Grenoble \& Lindsay J. Whaley (eds.) Endangered Languages. Language loss and community response. Cambridge: Cambridge University Press, 192-216. 
Evans: Typologies of agreement - some problems from Kayardild

KeEn, Sandra, 1983. 'Yukulta', in R.M.W. Dixon and Barry J. Blake (eds.), Handbook of Australian Languages, Vol. 3, Canberra: Australian National University Press, 190-304.

KLOKEID, TERRY, 1976. Topics in Lardil grammar. Ph.D. Dissertation, MIT.

Lehmann, Christian \& Edith Moravcsik, 2000. 'Noun', in Geert Booij, Christian Lehmann \& Joachim Mugdan (eds.), Morphology: a Handbook on Inflection and Word Formation. Berlin: Mouton de Gruyter. Pp. 732-757.

Lyons, JoHn, 1968. Theoretical Linguistics. Cambridge: Cambridge University Press.

McConvell, PATRICK, 1981. 'How Lardil became accusative', Lingua 55: 141-179.

Matthews, P.H. 1997. Oxford Concise Dictionary of Linguistics. Oxford: Oxford University Press.

Mel'C[inset hachek]uK, IgoR, 1994. Cours de morphologie générale. Vol. 2. Deuxième partie: significations morphologiques. Montréal: Les Presses de l'Université de Montréal.

Mel'C[inset hachek]uK, IgoR, 1996. Cours de morphologie générale. Vol. 3. Troisième partie: moyens morphologiques. Quatrième partie: syntactiques morphologiques. Montréal: Les Presses de l'Université de Montréal.

Mel'c[inset hachek]uk, IgOR, 1997. Cours de morphologie générale. Vol. 4. Cinquième partie: signes morphologiques. Montréal: Les Presses de l'Université de Montréal.

MoravcsiK, EdiTh, 1978. 'Agreement', in Joseph H. Greenberg et al (eds.), Universals of Human Language, Vol. 4, Syntax. Stanford: Stanford University Press, 331-374.

Moravcsik, Edith A., 1995. 'Summing up Suffixaufnahme', in Frans Plank (ed.) Double Case. Agreement by Suffixaufnahme. Oxford: Oxford University Press, 451-484.

NoRDlinger, RaChel, 1998. Constructive Case: Evidence from Australian Languages. Stanford: CSLI.

Plank, Frans (ed.), 1995. Double case: agreement by Suffixaufnahme, Oxford: Oxford University Press.

Pollard, Carl \& Ivan A. Sag, 1988. 'An information-based theory of agreement'. CLS 24, Parasession on Agreement, 236-257.

Steele, Susan, 1978. 'Word order variation: a typological study', in Joseph H. Greenberg, Charles A. Ferguson \& Edith A. Moravcsik (eds.) Universals of Human Language: IV: Syntax. Stanford: Stanford University Press, 585-623.

TAYLOR, John R., 1995. Linguistic categorization. Prototypes in Linguistic Theory (Second Edition), Oxford: Clarendon Press. 


\begin{tabular}{|c|c|c|}
\hline Modal case & Semantic category & Corresponding verbal categories \\
\hline \multirow{4}{*}{$\begin{array}{l}\text { Locative } \\
\{\text {-kiya }\}\end{array}$} & \multirow[t]{4}{*}{ Instantiated } & Actual (affirmative \& negative) \\
\hline & & Immediate \\
\hline & & $\begin{array}{l}\text { [Potential (Affirmative \& Negative) giving 'actual } \\
\text { ability' meaning] }\end{array}$ \\
\hline & & $\begin{array}{l}\text { [Apprehensive, giving 'actually occurring } \\
\text { undesirable event' meaning] }\end{array}$ \\
\hline Proprietive & \multirow[t]{2}{*}{ Future } & Potential (Affirmative \& Negative) \\
\hline$\{-k u r u\}$ & & $\begin{array}{l}\text { [Apprehensive, giving 'future undesirable' } \\
\text { meaning] }\end{array}$ \\
\hline Ablative & \multirow[t]{2}{*}{ Prior } & \multirow[t]{2}{*}{ Past, Almost, Precondition } \\
\hline$\{-k i n a b a\}$ & & \\
\hline Oblique (-inja $\}$ & Emotive & $\begin{array}{l}\text { Apprehensive, Desiderative, Hortative (Affirmative } \\
\& \text { Negative) }\end{array}$ \\
\hline \multicolumn{3}{|l|}{-kiring } \\
\hline \multirow[t]{2}{*}{ Zero } & \multirow[t]{2}{*}{---} & Imperative (Affirmative \& Negative) \\
\hline & & Continuative nominalization \\
\hline
\end{tabular}

Table 1. Correspondences between modal case semantics and verbal TAMP in Kayardild Note: (i) Verbal categories listed in square brackets are relatively marked examples where the modal case is independently varied from the verbal TAMP for particular semantic effects (ii) modal case forms are cited in their canonical form 


\section{Evans: Typologies of agreement - some problems from Kayardild}

\begin{tabular}{|c|c|c|c|c|c|c|}
\hline Corbett criterion & $\begin{array}{l}\text { Case } \\
\text { agreement } \\
\text { (adnominal } \\
\text { relational) } \\
\text { across NP }\end{array}$ & $\begin{array}{l}\text { Modal case } \\
\text { or }\end{array}$ & $\begin{array}{l}\text { Complementiz } \\
\text { ing case }\end{array}$ & $\begin{array}{l}\text { Associating } \\
\text { case }\end{array}$ & $\begin{array}{l}\text { TAMP inflection } \\
\text { on nominals } \\
\text { bearing } \\
\text { verbalizing case }\end{array}$ & $\begin{array}{l}\text { TAMP } \\
\text { inflection on } \\
\text { verbs in a VC }\end{array}$ \\
\hline Controller present & $\sqrt{ }$ & $\sqrt{ }$ & $?$ & $\sqrt{ }$ & $\sqrt{ }$ & $\sqrt{ }$ \\
\hline $\begin{array}{l}\text { Controller has overt } \\
\text { features }\end{array}$ & $\sqrt{ }$ & $\sqrt{ }$ & $\mathrm{n} / \mathrm{a}$ & $\sqrt{ }$ & $\sqrt{ }$ & $\sqrt{ }$ \\
\hline Consistent controller & $\sqrt{ }$ & $\sqrt{ }$ & $?$ & $\sqrt{ }$ & $\sqrt{ }$ & $\sqrt{ }$ \\
\hline $\begin{array}{l}\text { Controller's part of } \\
\text { speech irrelevant }\end{array}$ & $\sqrt{ }$ & $\mathrm{n} / \mathrm{a}$ & $?$ & $\sqrt{ }$ & $\sqrt{ }$ & $\sqrt{ }$ \\
\hline Target bound & $\sqrt{ }$ & $\sqrt{ }$ & $\sqrt{ }$ & $\sqrt{ }$ & $\sqrt{ }$ & $\sqrt{ }$ \\
\hline $\begin{array}{l}\text { Inflectional marking } \\
\text { on target }\end{array}$ & $\sqrt{ }$ & $\sqrt{ }$ & $\sqrt{ }$ & $\sqrt{ }$ & $\sqrt{ }$ & $\sqrt{ }$ \\
\hline Marking obligatory & $\sqrt{ }$ & $\sqrt{ }$ & $\sqrt{ }$ & $\sqrt{ }$ & $\sqrt{ }$ & $\sqrt{ }$ \\
\hline Marking regular & $\sqrt{ }$ & $\sqrt{ }$ & $\sqrt{ }$ & $\sqrt{ }$ & $\sqrt{ }$ & $\sqrt{ }$ \\
\hline Marking alliterative & $\sqrt{ }$ & $\sqrt{ } \sim x$ & $\sqrt{ }$ & $\mathrm{x}$ & $\sqrt{ }$ & $\sqrt{ }$ \\
\hline Target productive & $\sqrt{ }$ & $\sqrt{ }$ & $\sqrt{ }$ & $\sqrt{ }$ & $\sqrt{ }$ & $\sqrt{ }$ \\
\hline Doubling $^{23}$ & $\sqrt{ }$ & $\sqrt{ }$ & $\sqrt{ }$ & $\sqrt{ }$ & $\sqrt{ }$ & $\sqrt{ }$ \\
\hline $\begin{array}{l}\text { Target agrees }{ }^{24} \text { with a } \\
\text { single controller }\end{array}$ & $\mathrm{x}$ & $\mathrm{x}$ & $\mathrm{x}$ & $\mathrm{x}$ & $\mathrm{x}$ & $\mathrm{x}$ \\
\hline $\begin{array}{l}\text { Target's part of } \\
\text { speech irrelevant }\end{array}$ & $\sqrt{ }$ & $\sqrt{ }$ & $\sqrt{ } 25$ & $\sqrt{ }$ & $\sqrt{ }$ & $\sqrt{ }$ \\
\hline Asymmetric & $\begin{array}{l}\text { Depends } \\
\text { analysis }\end{array}$ & $\begin{array}{r}\text { on Depends } \\
\text { analysis }\end{array}$ & on? & $\sqrt{ }$ & $\begin{array}{l}\text { Depends } \\
\text { analysis }\end{array}$ & $\sqrt{ }$ \\
\hline Local (within clause) & $\sqrt{ }$ & $\sqrt{ }$ & $\sqrt{ }$ & $\sqrt{ }$ & $\sqrt{ }$ & $\sqrt{ }$ \\
\hline $\begin{array}{l}\text { Domain is one of a } \\
\text { set }\end{array}$ & $?^{26}$ & $?$ & $\mathrm{x}$ & $\mathrm{x}$ & $\sqrt{ }$ & $\sqrt{ }$ \\
\hline Feature is lexical & $\mathrm{x}$ & $\mathrm{x}$ & $\mathrm{x}$ & $\mathrm{x}$ & $\mathrm{x}$ & $\mathrm{x}$ \\
\hline $\begin{array}{l}\text { Features have } \\
\text { matching values }\end{array}$ & $\sqrt{ }$ & $\mathrm{x}$ & $?$ & $\mathrm{x}$ & $\sqrt{ }$ & $\sqrt{ }$ \\
\hline $\begin{array}{l}\text { No choice of feature } \\
\text { value }\end{array}$ & $\sqrt{ }$ & $\mathrm{x}$ & $\sqrt{ }$ & $\sqrt{ }$ & $\sqrt{ }$ & $\sqrt{ }$ \\
\hline No conditions & $\sqrt{ }$ & $\sqrt{ }$ & $\mathrm{x}^{27}$ & $\sqrt{ }$ & $\mathrm{x}^{28}$ & $\sqrt{ }$ \\
\hline
\end{tabular}

\footnotetext{
${ }^{23}$ I.e. occurs 'irrespective of the presence or absence of the controller' (Corbett 2002:23)

${ }^{24}$ Since the target is taken to be the word, and since all words participating in constructions discussed here can take multiple agreement emanating from different syntactic levels, in no case is there restriction to a single controller. However, if the target is taken to be a given morphological slot, instead of the word as whole, then in each case the target would agree with just one controller.

25 Though realization blocked on pronouns for complementizing locative.

${ }^{26}$ Whether this counts as a single case, or one of a set, depends on theory-specific assumptions about how far all instances of agreement inside the same NP count as 'the same' phenomenon (e.g. of demonstratives with nouns, of adjectives with nouns etc.), and further of whether cases of recursion count as 'the same' phenomenon applied more than once, or different 'levels' at which the phenomenon applies. Similar problems apply to the situation with modal case.

${ }^{27}$ Blocking of complementizing case on pronouns that should take the complementizing locative is here treated as a condition.
} 
Evans: Typologies of agreement - some problems from Kayardild

\begin{tabular}{|c|c|c|c|c|c|c|c|}
\hline $\begin{array}{l}\text { Score on } \\
\text { tests } \\
\text { (out of } 20 \text { ) }\end{array}$ & Corbett & $16 \sim 17$ & $12 \sim 13$ & 10 & 15 & $16 \sim 17$ & 18 \\
\hline $\begin{array}{l}\text { Endocentric } \\
\text { exocentric }^{29}\end{array}$ & & Endo & Exo & Endo & Exo & Exo & Endo \\
\hline
\end{tabular}

Table 2: Corbett's criteria for canonical agreement, applied to Kayardild

${ }^{28}$ Condition: has to be a NP bearing verbal case.

${ }^{29}$ This test, not in Corbett, is from Lyons (1968:241), who argues that government must be exocentric, while agreement can be either. 
Evans: Typologies of agreement - some problems from Kayardild

\begin{tabular}{|c|c|c|c|c|c|c|}
\hline Corbett principle & $\begin{array}{l}\text { Case } \\
\text { agreement } \\
\text { (adnominal } \\
\text { or relational) } \\
\text { across NP }\end{array}$ & Modal case & $\begin{array}{l}\text { Complementiz } \\
\text { ing case }\end{array}$ & $\begin{array}{l}\text { Associating } \\
\text { case }\end{array}$ & $\begin{array}{l}\text { TAMP } \\
\text { inflection on } \\
\text { nominals } \\
\text { bearing } \\
\text { verbalizing } \\
\text { case }\end{array}$ & $\begin{array}{l}\text { TAMP } \\
\text { inflection on } \\
\text { verbs in a VC }\end{array}$ \\
\hline $\begin{array}{l}\text { Redundant rather than } \\
\text { informative }\end{array}$ & $\sqrt{ }$ & $\sqrt{ }(95 \%)$ & Mixed & $\begin{array}{l}\text { See } \\
\text { discussion }\end{array}$ & $\sqrt{ }$ & $\sqrt{ }$ \\
\hline Syntactically simple & $\sqrt{ }$ & $\sqrt{ }$ & $\sqrt{ }$ & $\sqrt{ }$ & $\sqrt{ }$ & $\sqrt{ }$ \\
\hline $\begin{array}{l}\text { Canonically } \\
\text { inflectional }\end{array}$ & $\sqrt{ }$ & $\sqrt{ }$ & $\sqrt{ }$ & $\sqrt{ }$ & $\sqrt{ }$ & $\sqrt{ }$ \\
\hline Score & 3 & 3 & $2-3$ & $2-3$ & 3 & 3 \\
\hline
\end{tabular}

Table 3: Corbett's three principles for canonical agreement, applied to Kayardild 
Key words for indexing:

\author{
agreement \\ concord \\ case \\ multiple case \\ case-stacking \\ Suffixaufnahme \\ Modal case \\ Verbalizing case \\ double case-marking
}

Kayardild

Lardil

Word class

Tangkic languages

Australian languages

Symmetrical agreement

Tense

Mood

modality 